\title{
Karakteristik Air Tanah Dangkal Kota Semarang Pada Musim Penghujan Berdasarkan Pendekatan Isotop Stabil $\left({ }^{18} \mathrm{O},{ }^{2} \mathrm{H}\right)$ dan Kimia Air
}

\section{Characteristics of Shallow Groundwater of Semarang City in the Rainy Season Based on Stable Isotopes $\left({ }^{18} \mathrm{O},{ }^{2} \mathrm{H}\right)$ and Water Chemistry}

\author{
Satrio $^{1}$, Hendarmawan ${ }^{2}$, M. Sapari Dwi Hadian ${ }^{2}$ dan E. Ristin \\ Pujiindiyati $^{1}$ \\ ${ }^{1}$ Pusat Aplikasi Isotop dan Radiasi, BATAN \\ Jl. Lebak Bulus Raya No. 49, Jakarta Selatan 12440 \\ ${ }^{2}$ Fakultas Teknik Geologi Universitas Padjadjaran, Bandung \\ Jl. Raya Bandung Sumedang KM 21, Jatinangor 45363 \\ Email : satrio@batan.go.id
}

Diterima 26-02-2015; Diterima dengan revisi 10-03-2015; Disetujui 26-05-2015

\begin{abstract}
ABSTRAK
Karakteristik Air Tanah Dangkal Kota Semarang Pada Musim Penghujan Berdasarkan Pendekatan Isotop Stabil $\left({ }^{18} \mathbf{O},{ }^{2} \mathbf{H}\right)$ dan Kimia Air. Pada bulan Maret 2014 telah dilakukan penelitian air tanah di wilayah Kota Semarang dengan tujuan untuk mengetahui karakteristik air tanah dangkal pada saat musim penghujan melalui pendekatan isotop stabil $\left({ }^{18} \mathrm{O},{ }^{2} \mathrm{H}\right)$ dan kimia air yang didukung dengan data hidrogeologi setempat. Sejumlah sampel air tanah dangkal diambil di beberapa lokasi dengan kedalaman antara 0 $35 \mathrm{~m}$ di bawah permukaan tanah setempat (dbpts). Analisis isotop stabil ${ }^{18} \mathrm{O}$ dan ${ }^{2} \mathrm{H}$ serta kimia air dilakukan di laboratorium Hidrologi, Pusat Aplikasi Isotop dan Radiasi, BATAN Jakarta. Hasil analisis isotop stabil ${ }^{18} \mathrm{O}$ dan ${ }^{2} \mathrm{H}$ menunjukkan bahwa sekitar $63 \%$ air tanah cenderung berada di dekat garis meteorik Semarang dan sekitar $37 \%$ sisanya mengalami evaporasi, interaksi dengan oksida batuan dan sedikit pengaruh interaksi atau mixing dengan air laut. Dari hasil analisis kimia air dengan ionic balancesekitar $3 \%$ menunjukkan bahwa pada saat musim penghujan akuifer air tanah dangkal di wilayah Kota Semarang didominasi oleh ion bikarbonat $\left(\mathrm{HCO}_{3}{ }^{-}\right)$dengan tipe air didominasi $\mathrm{CaHCO}_{3}$. Sedangkan dari data parameter Chloride Bicarbonate Ratio, sekitar $24 \%$ air tanah dangkal di wilayah Kota Semarang terindikasi mengalami intrusi air laut dansisanya sekitar $76 \%$ masih menunjukkan karakteristik sebagai air tanah tawar.
\end{abstract}

Kata kunci : karakteristik air tanah, air tanah dangkal, Semarang, musim penghujan, isotop stabil dan kimia air

\begin{abstract}
Characteristics of Shallow Groundwater of Semarang City in the Rainy Season Based on Stable Isotopes $\left({ }^{18} \mathbf{O},{ }^{2} \mathbf{H}\right)$ and Water Chemistry. In March 2014 a research has been conducted of groundwater in the area of Semarang aimed to determine the characteristics of shallow groundwater in rainy season by using stable isotopes $\left({ }^{18} \mathrm{O},{ }^{2} \mathrm{H}\right)$ and water chemistry, also supported by local hydrogeologic data. A number of shallow groundwater samples were taken at several locations at a depth of 0-35 $\mathrm{m}$ from the subsurface. Analysis of stable isotopes $\left({ }^{18} \mathrm{O},{ }^{2} \mathrm{H}\right)$ and water chemistry were done in the Hydrology laboratory, Isotopes and Radiation Application Center, BATAN Jakarta. The results of the analysis of stable isotopes ${ }^{18} \mathrm{O}$ and ${ }^{2} \mathrm{H}$ showed that the characteristics of shallow groundwater during the rainy season is around $63 \%$ and tend to be the meteoric water line of Semarang and about $37 \%$ was evaporated, the interaction with the oxide rocks or mixing with water sea. The results of chemical analysis of water with the ionic balance is around $3 \%$ indicating that during the rainy season shallow groundwater aquifers in the city of Semarang
\end{abstract}


was dominated by bicarbonate $\left(\mathrm{HCO}_{3}{ }^{-}\right)$with water type was dominated by $\mathrm{CaHCO}_{3}$. While the data parameter Bicarbonate Chloride Ratio Ratio, shallow groundwater during the rainy season, where about is $24 \%$ indicated by the intrusion of sea water and the remaining approximately $76 \%$ showedcharacteristics as fresh groundwater.

Key word: groundwater characteristics, shallow groundwater, Semarang, rainy season, stable isotopes and water chemistry

\section{PENDAHULUAN}

Air tanah merupakan salah satu kebutuhan pokok bagi manusia, baik untuk kebutuhan air minum maupun untuk berbagai keperluan lainnya. Kebutuhan terhadap air semakin lama semakin meningkat seiring pertumbuhan penduduk dan perkembangan industri. Air yang dikenal dengan sebutan white gold merupakan kebutuhan yang sangat penting bagi kehidupan, sehingga kualitas dan kuantitas sumber daya airperlu terus dijaga dan dilestarikan. Namun disisi lain, peningkatan jumlah penduduk dan kebutuhan air ini memberikan dampak yang nyata terhadap perubahan lingkungan, khususnya kondisi air tanah [1].

Pada beberapa dasawarsa terakhir ini, eksploitasi air tanah, baik air tanah pada bagian akuifer dangkal maupun akuifer dalam terus meningkat sangat pesat. Fenomena tersebutapabila tidak dikendalikan akan berdampak terhadap kuantitas maupun kualitas air tanah, seperti penurunan muka tanah, penurunan kualitas air dan kejadian intrusi air laut. Eksploitasi air tanah yang tidak terkontrol dapat mengakibatkan dampak negatif terhadap keseimbangan alam itu sendiri [2].

Dalam beberapa tahun terakhir diketahui bahwa di beberapa lokasi diwilayah Kota Semarang bagian utara telah terjadi penyusupan air asin terus meningkat [3], terutama pada daerah pemukiman pusat perkotaan dan di beberapa wilayah industri di bagian utara, misalnya daerah sekitar Muara Kali Garang, Tanah Mas, Pengapon, Simpang Lima. Penyusupan air asin terindikasi dari hasil pemantauan pada beberapa sumur gali penduduk yang tersebar, maupun dari kualitas sumur bor di beberapa tempat. Diwilayah Semarang penyusupan air asin tersebut diperkirakan sudah mencapai sejauh $2 \mathrm{~km}$ ke arah selatan garis pantai. Daerah Kendal penyusupan air asin, terdeteksi di utara Kaliwungu, Murorejo, Kumpulrejo sampai sekitar Sukolilan. Sumur bor yang dikelola oleh PDAM Kendal, di kampung Pegandon air tanahnya sudah dipengaruhi oleh penyusupan air asin, yang diperkirakan sebagai akibat kurang sempurnanya sistem konstruksi sumurbor. Nilai daya hantar listrik (DHL) air sumur bor tersebut melebihi 2000 umhos/cm, dengan jarak lokasi sumur bor dari garis pantai kurang lebih $5 \mathrm{~km}$.Pola salinitas pada air tanah yang dilakukan melalui pengukuran DHL meningkat dari 1995 - 2008 [4].

Dengan permasalahan tersebut, penting dilakukan penelitian dengan metode isotop, kimia air dan geologi sehingga, diperoleh data maupun peta mengenai penyebaran air laut secara lebih aktual. Metode isotop stabil ${ }^{18} \mathrm{O}$ dan ${ }^{2} \mathrm{H}$ merupakan salah satu "tool" dalam mempelajari asalusul air tanah. Kedua isotop tersebut bersifat stabil dan dalam penelitian hidrologi digunakan sebagai sidik jari (finger print) untuk mengetahui asal-usul air dan dapat membedakan berbagai sumber air seperti air hujan, air tanah, air laut, air magmatik dan air konat (connate water) [5].

Intrusi atau penyusupan air asin ke dalam akuifer di daratan pada dasarnya adalah proses masuknya air laut di bawah permukaan tanah melalui akuifer di daratan atau daerah pantai. Dalam pengertian lain, yaitu proses terdesaknya air bawah tanah tawar oleh air asin/air laut di dalam akuifer pada daerah pantai [6].

Interaksi antara air tanah dengan air laut dapat diteliti melalui pendekatan metode isotop stabil ${ }^{18} \mathrm{O},{ }^{2} \mathrm{H}$ dan kimia air serta didukung dengan geologi. Secara 
teoritis, kandungan isotop air laut memiliki kandungan isotop, baik ${ }^{18} \mathrm{O}$ dan ${ }^{2} \mathrm{H}$ sebesar 0 \%o. Air tanah yang mengalami mixing dengan air laut cenderung memiliki kandungan isotop lebih enrich dibandingkan kandungan isotop air tanah pada kondisi normal. Kandungan kimia air juga digunakan dalam memvalidasi hasil analisis isotop, baik melalui pendekatan carbonate bicarbonate maupun melalui diagram piperyang digunakan untuk mengetahui tipe air [7].

\section{HIDROGEOLOGI DAERAH PENELITIAN}

Sistem akuifer air tanah Semarang dapat dilihat melalui peta hidrogeologi Semarang pada Gambar 1 di bawah ini. Berdasarkan kondisi geologi dan pembentukannya, sistem air tanah di wilayah Kota Semarang dapat dibagi menjadi dua sistem air tanah [8], yaitu:

\section{a. Sistem akuiferdi daerah dataran}

Sistem akuifer ini terdiri dari akuifer tak tertekan (unconfined) yang kedalamannya antara 5 hingga $30 \mathrm{~m}$ di bawah permukaan tanah setempat (dbpts) dan akuifer tertekan (confined) terdiri dari delta akuifer Delta Garang dan akuifer Formasi Damar. Kedalaman kedua akuifer tersebut antara 30 hingga $130 \mathrm{~m}$ dbpts dan bersifat semi tertekan dan tertekan.

Akuifer tak tertekan (unconfined aquifer).

Akuifer tak tertekan berada dekat permukaan tanah dan muka air tanahnya berhubungan langsung dengan udara bebas atau sering disebut sebagai air tanah bebas. Akuifer bagian bawahnya merupakan lapisan kedap air, sedangkan bagian atasnya merupakan material berbutir halus. Pengamatan di lapangan terhadap beberapa sumur gali di dataran Semarang menunjukkan bahwa kedalaman muka air tanah dangkal berkisar antara 0,2 hingga 3,0 $\mathrm{m}$ dbpts, sedangkan kedalaman sumur gali

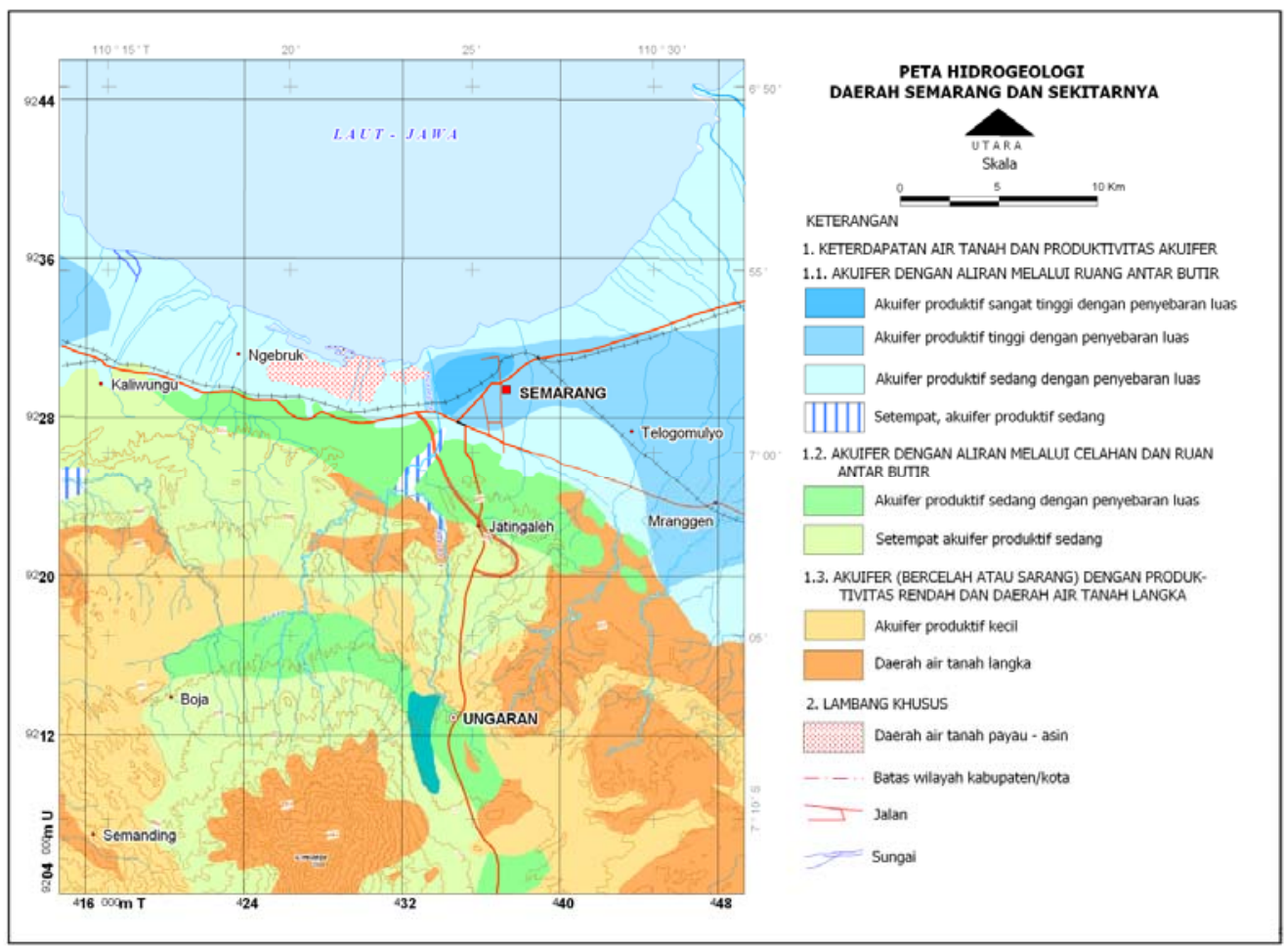

Gambar 1. Peta hidrogeologi Semarang [9] 
di dataran tersebut umumnya berkisar antara 6 hingga $12 \mathrm{~m}$ dbpts.

\section{Akuifer tertekan}

Akuifer tertekan yaitu yang bagian atas dan bawahnya merupakan lapisan kedap air, dimana tekanan airnya lebih besar dari tekanan atmosfer. Pada lapisan pembatasnya tidak ada air yang mengalir. Akuifer di dataran Semarang mempunyai kedalaman 30 hingga 70 dbpts. Batuan pembentuk akuifer tersebut terdiri dari lensa-lensa pasir dan kerikil yang ditutupi oleh lapisan lempung atau lempung pasiran sehingga airnya bersifat semi tertekan atau tertekan.

\section{b. Sistem akuifer di daerah perbukitan}

Sistem akuifer di daerah perbukitan dibagi menjadi dua, yaitu:

\section{Akuifer tak tertekan}

Akuifer tak tertekan di daerah perbukitan merupakan akuifer Formasi Notopuro dan akufer Ungaran Tua bersifat tak tertekan. Muka air tanahnya berkisar antara 8 - $15 \mathrm{~m}$ dbpts, kedalamannya 10 $30 \mathrm{~m}$ dbpts. Di beberapa tempat, muka air tanahnya mencapai lebih dari $20 \mathrm{~m}$ dbpts, tetapi pada tempat yang lain air tanahnya muncul sebagai mata air.

\section{Akuifer tertekan - semi tertekan}

Akuifer tertekan - semi tertekan berupa pasir vulkanik, breksi vulkanik dan konglomerat dari akuifer Formasi Damar yang tersebar merata di daerah perbukitan. Akuifer ini umumnya berada pada kedalaman antara 30 - $150 \mathrm{~m}$ dbpts.

\section{BAHAN DAN METODE}

\section{Bahan}

Bahan penelitian terdiri atas botol plastik berkapasitas $30 \mathrm{ml}$ untuk sampel isotop stabil ${ }^{18} \mathrm{O}$ dan ${ }^{2} \mathrm{H}$, botol plastik berkapasitas $500 \mathrm{ml}$ untuk sampel kimia air, larutan $\mathrm{HNO}_{3}$ untuk treatment sampel kation, pipet tetes, probe pipet, dry rit dan syringe CTC $1,2 \mu \mathrm{L}$.

\section{Metode}

\section{Pengambilan sampel}

Isotop stabil ${ }^{18} \mathrm{O}$ dan ${ }^{2} \mathrm{H}$ berada di air dalam bentuk senyawa ${ }^{1} \mathrm{H}_{2}{ }^{18} \mathrm{O}$ dan ${ }^{1} \mathrm{H}^{2} \mathrm{H}^{16} \mathrm{O}_{2}$. Kedua isotop tersebut sangat peka terhadap proses fisika seperti evaporasi dan kondensasi. Oleh karena itu, untuk mencegah hal tersebut maka pengambilan sampel air dilakukan sebagai berikut:

a. Sampel air sebanyak $20 \mathrm{ml}$ dimasukan kedalam botol khusus kedap udara dengan cara mendekatkan botol terhadap sumber air atau memasukannya kedalam sumber.

b. Hindarkan adanya gelembung udara dalam sampel dengan cara memasukan sampel secara pelahan-lahan.

c. Setelah sampel terisi penuh dan tidak ada gelembung udara tutup botol tersebut hingga kedap udara.

Pengambilan sampel kimia air untuk analisis kimia air dilakukan dengan mengambil sampel air sebanyak $500 \mathrm{ml}$ untuk anion dan $500 \mathrm{ml}$ untuk kation. Sampel air untuk analisis kation biasanya ditambahkan larutan asam sebanyak3 tetes untuk menghindari pengendapan ion dan perubahan sifat akibat bakteri.

\section{Analisis sampel}

Analisis komposisi isotop isotop dilakukan menggunakan Liquid-water stable isotope analyzer LGR (Los Gatos Research) DLT-100. Sedangkan analisis kimia air dilakukan menggunakan alat Ion Chromatography (IC).

\section{Pendekatan isotop stabil ${ }^{18} \mathrm{O}$ dan ${ }^{2} \mathrm{H}$}

Melalui pendekatan metode isotop stabil ${ }^{18} \mathrm{O},{ }^{2} \mathrm{H}$ dan kimia air serta didukung dengan geologi, dapat diketahui mengenai pola penyebaran intrusi daerah penelitian dan tingkat pencemaran pada masingmasing lokasi. Secara teoritis, kandungan isotop air laut memiliki kandungan isotop 0 \%o dan air tanah yang mengalami percampuran atau mixing dengan air laut 
cenderung memiliki kandungan isotop lebih enrich dibandingkan kandungan isotop air tanah pada kondisi normal. Air tanah yang mengalami percampuran dengan air laut cenderung berada pada garis mixing seperti terlihat pada Gambar 2 di bawah ini.Grafik hubungan antara isotop ${ }^{18} \mathrm{O}$ dan ${ }^{2} \mathrm{H}$ merupakan pendekatan yang umum digunakan untuk identifikasi fenomena intrusi laut pada suatu daratan [10].

Pendekatan lain yang umum digunakan adalah hubungan antara isotop ${ }^{18} \mathrm{O}$ dan ion klorida $\left(\mathrm{Cl}^{-}\right)$. Pada air tanah yang mengalami mixing dengan air laut, pergeseran isotop ${ }^{18} \mathrm{O}$ dan ${ }^{2} \mathrm{H}$ biasanya diikuti juga dengan perubahan konsentrasi ion klorida [11]. baik dalam air laut maupun air tanah, hanya persentasenya saja yang berbeda, misalnya ion klorida secara alami akan dominan di air laut dan sedikit di air tawar, sebaliknya ion karbonat atau bikarbonat dominan di air tawar dan sedikit di air laut.

Terdapat beberapa pendekatan kimia air untuk mengetahui adanya intrusi air laut, antara lain Molar rasio Chloride Bicarbonate dan melalui evaluasi diagram piper.Untuk mengetahui adanya intrusi tersebut dapat ditentukan dengan analisis kimia yang disebut "perbandingan klorida bikarbonat".Pada kasus ini dapat diketahui bahwa ion $\mathrm{Cl}^{-}$dan $\mathrm{Na}^{+}$lebih dominan pada air laut, sedangkan pada air tanah tawar, ion yang dominan adalah $\mathrm{CO}_{3}{ }^{2-}$ dan $\mathrm{HCO}_{3}$ $[13,14]$.

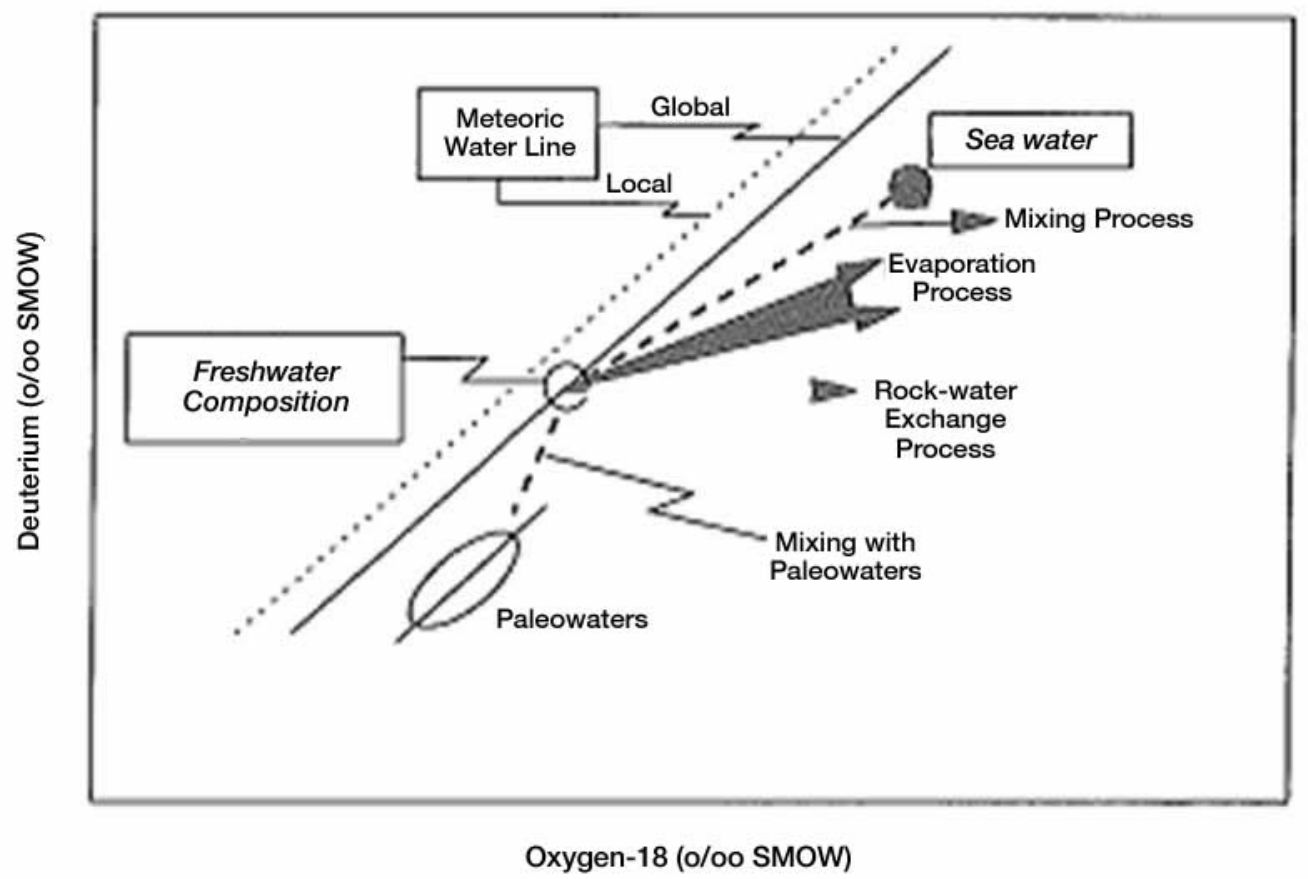

Gambar 2. Karakteristik isotop ${ }^{18} \mathrm{O}$ dan ${ }^{2} \mathrm{H}$ dalam berbagai proses [12]

\section{Pendekatan kimia air}

Indikasi adanya intrusi air laut dapat diketahui pula melalui pendekatan kimia air. Terdapat delapan ion yang dapat dijadikan indikasi adanya intrusi air laut, yaitu $\mathrm{Cl}^{-}, \mathrm{SO}_{4}{ }^{2-}, \mathrm{CO}_{3}{ }^{2-}, \mathrm{HCO}_{3}{ }^{-}, \mathrm{Na}^{+}, \mathrm{Ca}^{+}, \mathrm{Mg}^{+}$ dan $\mathrm{K}^{+}$. Kedelapan ion tersebut selalu ada,

$$
C B R=\frac{\mathrm{Cl}^{-}}{\mathrm{CO}^{2-}+\mathrm{HCO3}^{-}}
$$

Perbandingan klorida bikarbonat dalam berbagai nilai dan kondisi air tanah dapat dilihat pada Tabel 1 . 
Tabel 1. Perbandingan klorida bikarbonat dalam berbagai kondisi air tanah [15]

\begin{tabular}{cl}
\hline Rasio $\mathrm{Cl}^{-} /\left(\mathrm{CO}_{3}^{2-}+\mathrm{HCO}_{3}{ }^{-}\right)$ & \multicolumn{1}{c}{ Tingkat Intrusi Air Laut } \\
\hline$<0,5$ & Air tanah tawar (fresh groundwater) \\
$0,5-1,30$ & Terjadi intrusi air laut sedikit \\
$1,30-2,80$ & Terjadi intrusi air laut sedang \\
$2,80-6,60$ & Terjadi intrusi air laut agak tinggi \\
$6,60-15,50$ & Terjadi intrusi air laut tinggi \\
$15,5-20$ & Air laut \\
\hline
\end{tabular}

Berdasarkan data kimia air, yaitu delapan ion $\mathrm{Cl}^{-}, \mathrm{SO}_{4}{ }^{2-}, \mathrm{CO}_{3}{ }^{2-}, \mathrm{HCO}_{3}{ }^{-}, \mathrm{Na}, \mathrm{Ca}$, $\mathrm{Mg}$ dan Kdapat pula diketahui mengenai tipikal dari sampel air dan evolusi kimia air dari setiap lokasi berdasarkan diagram piper [16]. Secara umum, interpretasi data kimia air menggunakan diagram piper dapat digambarkan pada Gambar 3.
Panasbumi, Pusat Aplikasi Isotop dan Radiasi (PAIR) - BATAN yang meliputi analisis isotop stabil ${ }^{18} \mathrm{O}$ dan ${ }^{2} \mathrm{H}$ menggunakan Liquid-water stable isotope analyzer LGR (Los Gatos Research) DLT-100. Hasilnya dapat dilihat pada Tabel 2 di bawah ini. Data isotop stabil ${ }^{18} \mathrm{O}$ dan ${ }^{2} \mathrm{H}$ pada Tabel 2 tersebut selanjutnya diplotkan

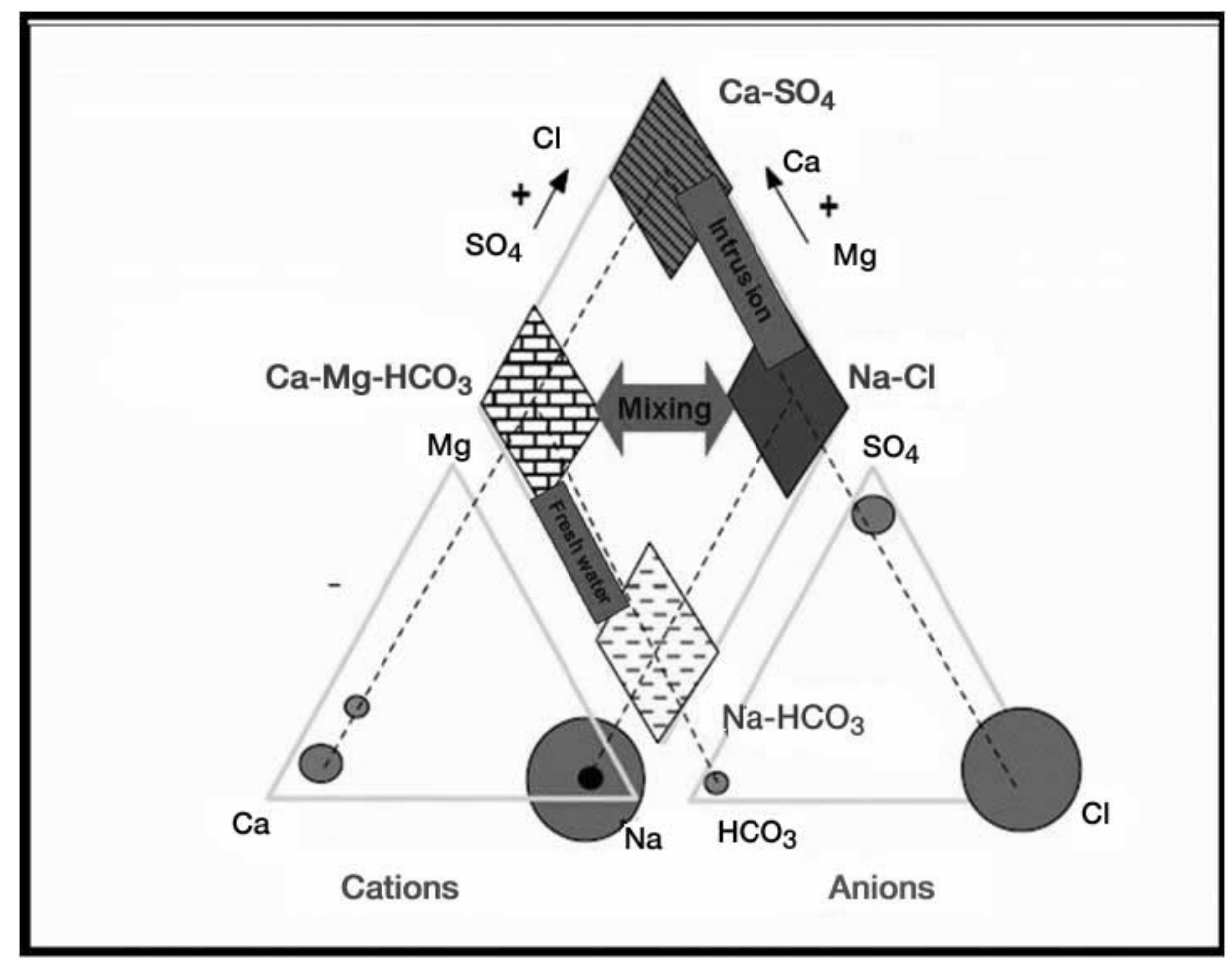

Gambar 3. Interpretasi tipikal air tanah dengan diagram piper [17]

\section{HASIL DAN PEMBAHASAN}

\section{Hasil analisis isotop stabil ${ }^{18} \mathrm{O}$ dan ${ }^{2} \mathrm{H}$}

Analisis terhadap sampel-sampel air tanah dilakukan di lab Hidrologi dan dalam bentuk grafik hubungan antara isotop ${ }^{2} \mathrm{H}$ terhadap isotop ${ }^{18} \mathrm{O}$ untuk mengetahui tipikal dari sampel-sampel air yang telah dianalisis. Grafiknya dapat dilihat pada Gambar 4 di bawah ini. Terlihat bahwa pada 
pengambilan sampel air tanah yang telah dilakukan pada bulan Maret 2014 atau mewakili musim penghujan, komposisi isotopnya memiliki kandungan yang relatif depleted dan cenderung lebih banyak berada dekat dengan garis meteorik atau garis hujan lokal Semarang. Ini menunjukkan pula bahwa pada musim penghujan, sebagian akuifer dangkal di Kota Semarang lebih dominan terisi air hujan secara langsung dan sebagian kecil lainnya mengalami proses pencampuran dengan air laut. Berdasarkan

Tabel 2. Hasil analisis isotop stabil ${ }^{18} \mathrm{O}$ dan ${ }^{2} \mathrm{H}$ air tanah dangkal wilayah Kota Semarang

\begin{tabular}{|c|c|c|c|}
\hline No. & Lokasi Sampel & $\delta^{18} \mathrm{O}(\%)$ & $\delta^{2} \mathrm{H}(\% 0)$ \\
\hline 1 & Karang Nangka & $-6,15$ & $-40,6$ \\
\hline 2 & Wonosari & $-5,88$ & $-43,2$ \\
\hline 3 & Rowosari & $-6,62$ & $-41,0$ \\
\hline 4 & Krajan & $-5,73$ & $-44,5$ \\
\hline 5 & Tanggulsari & $-4,90$ & $-40,1$ \\
\hline 6 & Pondok & $-5,42$ & $-39,9$ \\
\hline 7 & Margosari & $-6,73$ & $-46,2$ \\
\hline 8 & Puspagiwang & $-6,57$ & $-44,1$ \\
\hline 9 & Puswoyoso & $-7,07$ & $-47,6$ \\
\hline 10 & Pasadena & $-6,87$ & $-42,5$ \\
\hline 11 & Tugu Lapangan & $-7,21$ & $-47,1$ \\
\hline 12 & Karanganyar & $-6,58$ & $-36,6$ \\
\hline 13 & Tugurejo & $-7,22$ & $-42,8$ \\
\hline 14 & Ngliwonan & $-7,34$ & $-46,9$ \\
\hline 15 & Tambakharjo & $-5,30$ & $-41,4$ \\
\hline 16 & Kendeng & $-6,57$ & $-43,8$ \\
\hline 17 & Kalialang & $-6,34$ & $-42,4$ \\
\hline 18 & Manyaran & $-6,10$ & $-45,3$ \\
\hline 19 & Purianjosmoro & $-4,79$ & $-35,8$ \\
\hline 20 & Dorowati & $-6,64$ & $-45,4$ \\
\hline 21 & Lemah gempal & $-6,92$ & $-48,6$ \\
\hline 22 & Lempongsari & $-6,68$ & $-45,9$ \\
\hline 23 & Tengger & $-6,76$ & $-46,2$ \\
\hline 24 & Deliksari & $-6,17$ & $-42,3$ \\
\hline 25 & Bongsari & $-6,88$ & $-45,4$ \\
\hline 26 & Bidaken & $-6,35$ & $-46,8$ \\
\hline 27 & Tanah Mas & $-5,26$ & $-36,6$ \\
\hline 28 & Kepatihan & $-4,63$ & $-33,1$ \\
\hline 29 & Petelan & $-6,64$ & $-41,3$ \\
\hline 30 & Wonodri & $-6,04$ & $-42,9$ \\
\hline 31 & Candi sari & $-6,55$ & $-46,2$ \\
\hline 32 & Jongli & $-6,06$ & $-38,1$ \\
\hline 33 & Terboyo & $-5,54$ & $-43,2$ \\
\hline 34 & Sawah besar & $-5,43$ & $-42,0$ \\
\hline 35 & Sambirejo & $-6,39$ & $-38,9$ \\
\hline 36 & Gayomsari & $-6,28$ & $-40,3$ \\
\hline 37 & Sendangguo & $-6,40$ & $-45,3$ \\
\hline 38 & Amposari & $-6,26$ & $-43,2$ \\
\hline 39 & Juwono & $-6,48$ & $-46,0$ \\
\hline 40 & Genuk & $-5,89$ & $-40,7$ \\
\hline 41 & Karangroto & $-6,77$ & $-42,7$ \\
\hline 42 & Genuksari & $-4,97$ & $-40,8$ \\
\hline 43 & Tlogorejo & $-5,97$ & $-39,6$ \\
\hline 44 & Pedurungan & $-6,07$ & $-42,2$ \\
\hline 45 & Penggaron & $-6,22$ & $-41,3$ \\
\hline 46 & Tlogomulyo & $-5,81$ & $-37,5$ \\
\hline 47 & Goden & $-6,30$ & $-41,2$ \\
\hline 48 & Meteseh & $-5,96$ & $-41,0$ \\
\hline 49 & Krapyak & $-7,11$ & $-42,0$ \\
\hline 50 & Air laut Marina Smg & 0,33 & $-13,8$ \\
\hline 51 & Air lautPelabuhan Smg & 0,45 & $-10,1$ \\
\hline 52 & Aair lautMaron Smg & 0,36 & $-8,2$ \\
\hline
\end{tabular}


grafik tersebut, secara umum air tanah Kota Semarang dapat dikelompokan menjadi dua kelompok, yaitu air tanah kelompok I: sebanyak 38 sampel atau sekitar $78 \%$ air tanah pada kelompok ini cenderung berada pada di dekat garis meteorik Semarang dengan kandungan isotop stabil ${ }^{18} \mathrm{O}$ dan ${ }^{2} \mathrm{H}$ yang relatif miskin atau depleted. Ini mengindikasikan bahwa air tanahnya berasal dari imbuhan lokal yang relatif sama. Air tanah pada kelompok I ini sebagianberada di dataran dan sebagian lagi berada di perbukitan. Sedangkan air tanah kelompok II: sebanyak 11 sampel atau sekitar $22 \%$ air tanah pada kelompok ini memiliki kandungan isotop ${ }^{18} \mathrm{O}$ dan ${ }^{2} \mathrm{H}$ yang relatif kaya (enrich) jika dibandingkan dengan air tanah kelompok I. Dari 11 sampel tersebut, 9 sampel atau sekitar $18 \%$ diantaranya berada di garis percampuran atau di garis mixing antara air tanah dangkal dengan air laut Semarang. Indikasi ini menguatkan dugaan bahwa pada 9 lokasi tersebut air tanahnya sudah terkontaminasi air laut. Ke sembilan lokasi tersebut terdiri atas Semarang Barat meliputi: Tanggulsari, Pondok dan Tambak Harjo serta Semarang Timur meliputi: Puri Anjosmoro, Tanah Mas, Kepatihan, Terboyo, Sawah Besar dan Genuksari.

\section{Hasil analisis kimia air}

Analisis kimia air dilakukan terhadap anion yang meliputi ion $\mathrm{Cl}^{-}, \mathrm{SO}_{4}^{2-}$ dan $\mathrm{HCO}_{3}{ }^{-}$ serta kation yang meliputi ionNa ${ }^{+}, \mathrm{K}^{+}, \mathrm{Ca}^{2+}$, $\mathrm{Mg}^{2+}$. Data hasil analisisi kimia selengkapnya dapat dilihat pada Tabel 3 . Dengan ionic balance rata-rata $2,7 \%$, persentase dari masing ion dapat dilihat melalui grafik pada Gambar 5. Berdasarkan grafik tersebut, persentasedari masingmasing ion pada saat musim penghujan adalah: $\mathrm{Na}^{+} 28,84 \% ; \mathrm{K}^{+} 1,37 \% ; \mathrm{Ca}^{2+} 12,54$ $\% ; \mathrm{Mg}^{2+} 8,07 \% ; \mathrm{Cl}^{-} 27,02 \% ; \mathrm{SO}_{4}^{2-5,84} \%$ dan

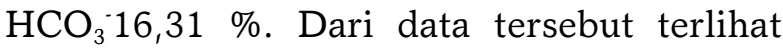
bahwa pada saat musim penghujan, air tanah dangkal wilayah KotaSemarang didominasi oleh ion $\mathrm{Na}, \mathrm{Cl}$ dan $\mathrm{HCO}_{3}$.

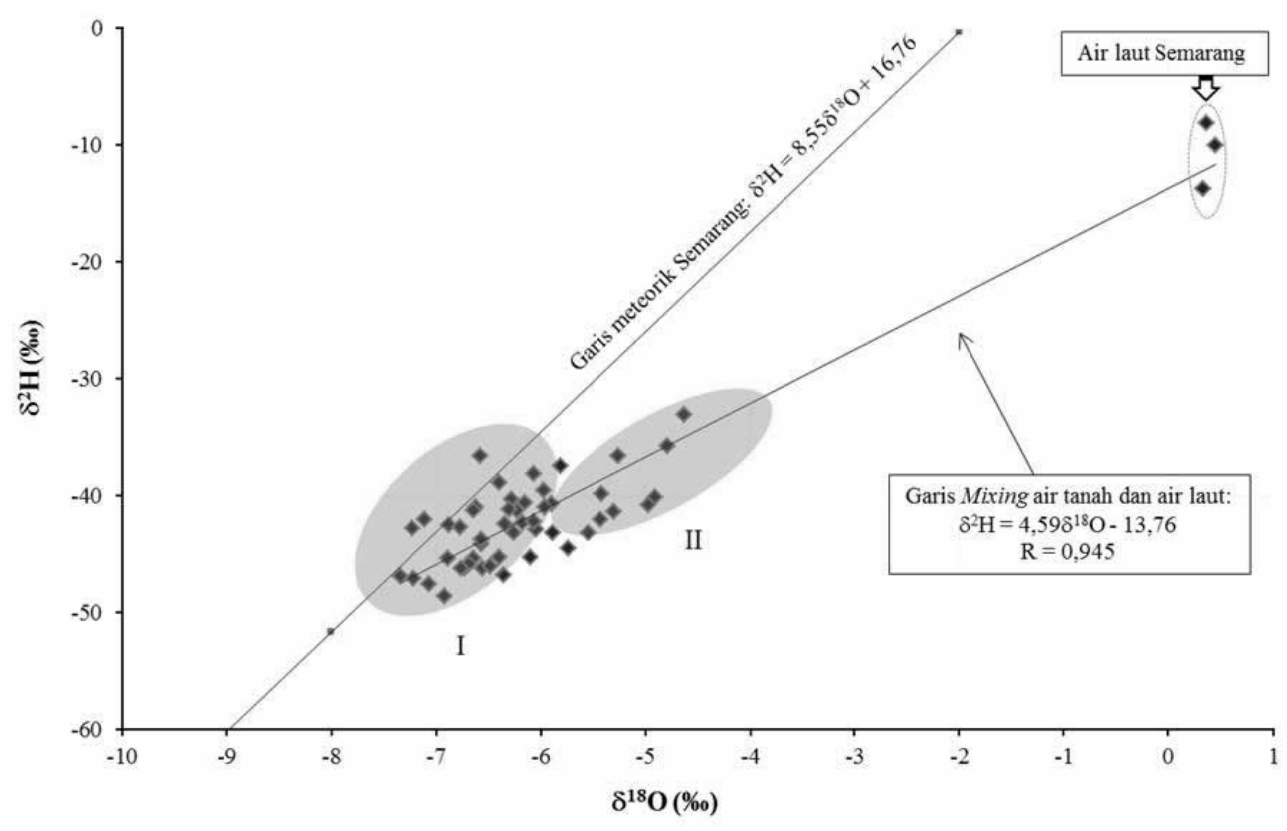

Gambar 4. Grafik hubungan isotop ${ }^{2} \mathrm{H}$ terhadap ${ }^{18} \mathrm{O}$ sampel air tanah dangkal wilayah Kota Semarang pada musim penghujan 
Tabel 3. Hasil analisis kimia air sampel air tanah dangkal wilayah Kota Semarang saat musim penghujan

\begin{tabular}{|c|c|c|c|c|c|c|c|c|}
\hline No. & Kode & $\begin{array}{c}\mathrm{Na}^{+} \\
(\mathbf{p p m})\end{array}$ & $\begin{array}{c}\mathrm{K}^{+} \\
(\mathbf{p p m})\end{array}$ & $\begin{array}{c}\mathrm{Ca}^{2+} \\
(\mathbf{p p m})\end{array}$ & $\begin{array}{l}\mathbf{M g}^{2+} \\
(\mathbf{p p m})\end{array}$ & $\begin{array}{c}\mathrm{Cl}^{-} \\
(\mathbf{p p m})\end{array}$ & $\begin{array}{l}\mathrm{SO}_{4}{ }^{2-} \\
(\mathrm{ppm})\end{array}$ & $\begin{array}{l}\mathrm{HCO}_{3}{ }^{-} \\
\text {(ppm) }\end{array}$ \\
\hline 1 & Tanggulsari & 156,29 & 13,98 & 14,20 & 5,74 & 165,03 & 43,00 & 167,08 \\
\hline 2 & Karang Nangka & 52,67 & 7,95 & 44,16 & 23,53 & 51,83 & 84,40 & 173,70 \\
\hline 3 & Wonosari & 94,54 & 14,71 & 77,82 & 42,24 & 126,10 & 73,00 & 350,72 \\
\hline 4 & Rowosari & 57,40 & 5,30 & 51,60 & 14,30 & 64,70 & 47,50 & 208,40 \\
\hline 5 & Krajan & 68,80 & 13,40 & 51,50 & 44,60 & 142,60 & 39,10 & 338,30 \\
\hline 6 & Pondok & 147,00 & 6,00 & 46,40 & 7,00 & 154,80 & 46,60 & 188,20 \\
\hline 7 & Margosari & 35,94 & 4,48 & 39,53 & 15,19 & 32,34 & 58,70 & 145,58 \\
\hline 8 & Puspagiwang & 177,00 & 10,10 & 18,53 & 1,85 & 65,51 & 73,00 & 268,00 \\
\hline 9 & Purwoyoso & 28,66 & 8,16 & 47,56 & 22,60 & 16,59 & 48,10 & 287,23 \\
\hline 10 & Pasadena & 30,75 & 3,13 & 43,23 & 9,63 & 17,00 & 40,30 & 162,95 \\
\hline 11 & Tugu Lapangan & 23,70 & 8,00 & 57,80 & 15,40 & 25,40 & 22,30 & 206,90 \\
\hline 12 & Karanganyar & 64,91 & 4,27 & 45,70 & 1,10 & 99,93 & 39,10 & 85,20 \\
\hline 13 & Ngliwonan & 19,37 & 8,15 & 47,25 & 14,27 & 21,56 & 30,00 & 191,11 \\
\hline 14 & Tugurejo & 109,90 & 20,50 & 78,00 & 25,80 & 112,90 & 45,60 & 378,00 \\
\hline 15 & Tambakharjo & 207,70 & 29,37 & 56,82 & 24,27 & 189,50 & 162,00 & 291,16 \\
\hline 16 & Krapyak & 111,05 & 7,20 & 81,70 & 20,10 & 156,60 & 85,00 & 276,60 \\
\hline 17 & Kendeng & 35,94 & 7,06 & 46,01 & 10,93 & 24,88 & 60,70 & 155,51 \\
\hline 18 & Kalialang & 59,70 & 4,50 & 81,80 & 13,00 & 48,90 & 58,00 & 281,20 \\
\hline 19 & Manyaran & 14,88 & 5,28 & 34,59 & 15,93 & 23,63 & 44,00 & 120,77 \\
\hline 20 & Puri Anjosmoro & 161,50 & 23,40 & 44,70 & 53,00 & 267,20 & 47,90 & 403,40 \\
\hline 21 & Dorowati & 90,43 & 20,87 & 44,78 & 23,16 & 65,93 & 86,00 & 256,40 \\
\hline 22 & Lemah Gempal & 21,23 & 6,05 & 47,56 & 21,31 & 21,56 & 43,60 & 200,17 \\
\hline 23 & Lempongsari & 35,26 & 9,41 & 47,86 & 10,56 & 31,93 & 54,60 & 139,94 \\
\hline 24 & Tengger & 12,70 & 6,30 & 61,20 & 4,10 & 19,80 & 20,40 & 153,50 \\
\hline 25 & Deliksari & 57,73 & 8,36 & 65,47 & 21,12 & 42,29 & 53,90 & 292,81 \\
\hline 26 & Bongsari & 56,50 & 8,50 & 62,40 & 12,10 & 55,10 & 35,80 & 265,40 \\
\hline 27 & Bidakan & 104,71 & 31,20 & 99,74 & 17,23 & 152,59 & 88,40 & 286,20 \\
\hline 28 & Tanah Mas & 3319,00 & 114,00 & 76,50 & 229,00 & 5470,00 & 100,70 & 655,30 \\
\hline 29 & Kepatihan & 73,79 & 35,15 & 56,82 & 17,42 & 130,30 & 64,90 & 242,36 \\
\hline 30 & Petelan & 112,90 & 41,00 & 83,70 & 21,70 & 133,90 & 34,00 & 349,10 \\
\hline 31 & Wonodri & 45,30 & 15,36 & 44,78 & 3,52 & 26,54 & 122,00 & 125,00 \\
\hline 32 & Candisari & 34,31 & 6,48 & 30,88 & 25,57 & 30,68 & 35,60 & 170,39 \\
\hline 33 & Jangli & 16,30 & 14,90 & 25,90 & 3,90 & 21,60 & 39,60 & 69,50 \\
\hline 34 & Terboyo & 450,90 & 26,40 & 81,70 & 27,00 & 574,50 & 86,30 & 379,70 \\
\hline 35 & Sawah Besar & 151,80 & 16,40 & 46,00 & 8,00 & 126,10 & 84,50 & 220,90 \\
\hline 36 & Sambirejo & 69,00 & 10,00 & 46,01 & 15,01 & 45,61 & 56,30 & 230,78 \\
\hline 37 & Gayamsari & 43,80 & 7,70 & 57,40 & 20,20 & 36,50 & 52,20 & 225,00 \\
\hline 38 & Sengdangguo & 66,80 & 10,00 & 33,97 & 37,80 & 52,24 & 88,00 & 331,86 \\
\hline 39 & Amposari & 48,92 & 12,62 & 51,26 & 18,90 & 34,00 & 112,00 & 173,70 \\
\hline 40 & Juwono & 24,85 & 13,30 & 35,51 & 29,27 & 15,76 & 34,50 & 253,50 \\
\hline 41 & Genuk & 75,00 & 7,20 & 121,70 & 24,30 & 75,50 & 119,00 & 360,60 \\
\hline 42 & Karangroto & 66,40 & 3,23 & 94,80 & 32,24 & 44,40 & 157,50 & 324,25 \\
\hline 43 & Genuksari & 155,80 & 5,94 & 50,03 & 21,12 & 173,32 & 101,30 & 268,83 \\
\hline 44 & Tlogorejo & 109,17 & 10,47 & 104,99 & 33,17 & 171,70 & 115,00 & 284,50 \\
\hline 45 & Pedurungan & 228,27 & 0,63 & 80,29 & 53,73 & 181,61 & 198,00 & 460,70 \\
\hline 46 & Penggaron & 41,50 & 3,80 & 128,50 & 18,30 & 30,30 & 132,00 & 327,60 \\
\hline 47 & Tlogomulyo & 71,20 & 8,30 & 67,90 & 26,70 & 76,30 & 88,80 & 346,70 \\
\hline 48 & Godean & 85,50 & 12,36 & 105,00 & 8,00 & 76,10 & 67,80 & 301,90 \\
\hline 49 & Meteseh & 31,05 & 5,98 & 100,05 & 13,15 & 33,69 & 27,40 & 371,31 \\
\hline
\end{tabular}

\section{Diagram piper}

Gambar 6 di bawah ini menunjukkan diagram piper mengenai tipikal air tanah dangkal Kota Semarang pada saat musim penghujan. Secara garis besar tipikal air tanah yang diambil pada musim penghujan tersebut dapat dikelompokan menjadi empat, yaitu sebanyak $69 \%$ merupakan freshwater dan sisanya sekitar $31 \%$ sebagai air tanah yang mengalami evolusi pada saat melalui batuan. Berdasarkan diagram piper tersebut terlihat bahwa sebagian besar air tanah yang diambil pada saat musim penghujan menempati sebelah kiri atas 


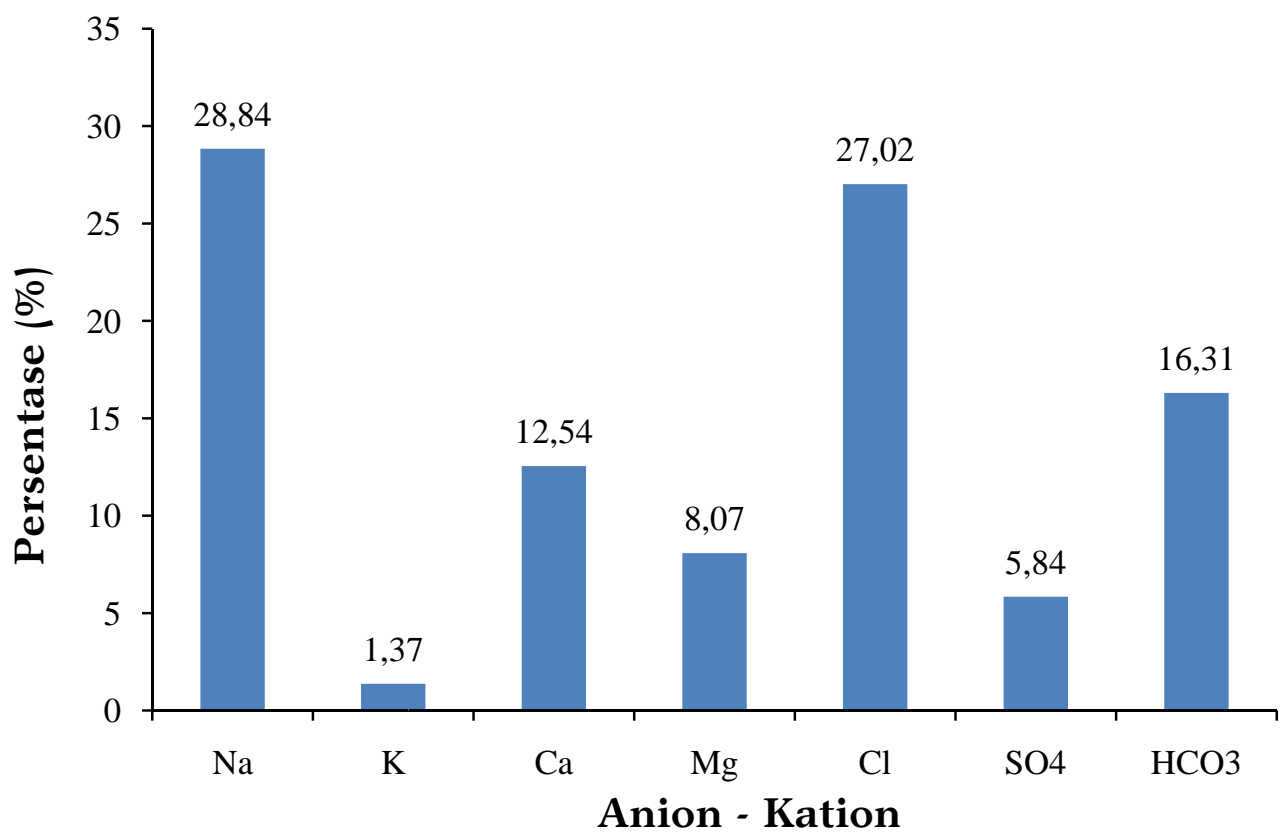

Gambar 5. Persentase masing-masing ion air tanah dangkal wilayah Kota Semarang pada musim penghujan

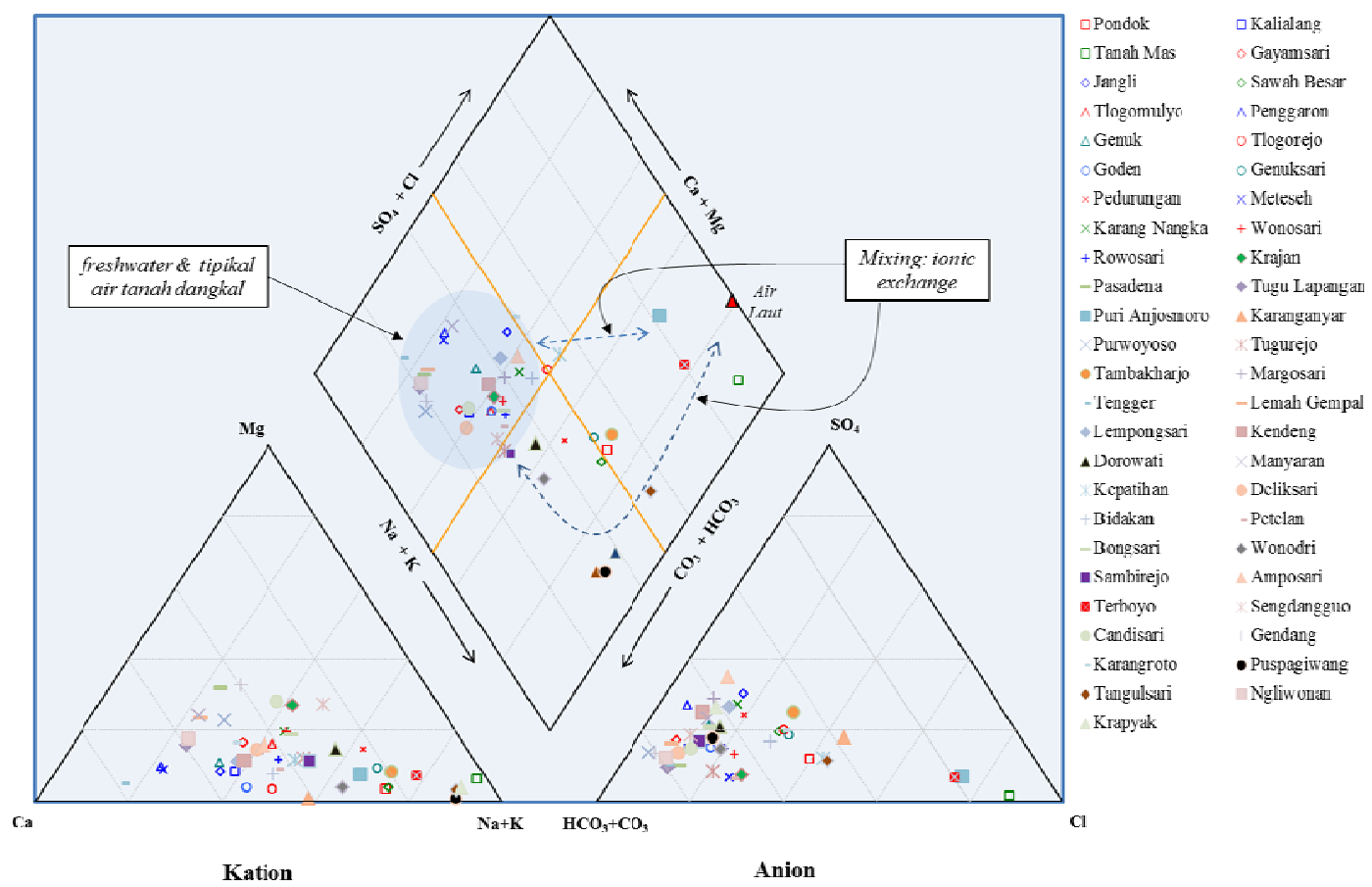

Gambar 6. Diagram piper pengambilan sampel air tanah dangkal Kota Semarang

jajaran genjang merupakan freshwater dengan tipe air $\mathrm{CaHCO}_{3}$ hingga $\mathrm{CaNaHCO}_{3}$. Keadaan ini diduga sangat dipengaruhi oleh kehadiran air hujan pada akuifer tanah dangkal karena sampel-sampel air tersebut diambil saat musim penghujan.Sedangkan 
sebagian lainnya merupakan air tanah yang mengalami evolusi dari freshwater menjadi air yang memiliki tipe $\mathrm{NaCaHCO}_{3} \mathrm{NaCaHCO}_{3} \mathrm{Cl}$ hingga $\mathrm{NaCl}$ yang merupakan air dengan tipikal campuran (mixing). Kehadiran $\mathrm{Ca}$ pada sebagian sampeldiduga berasal dari pelarutan batuan kalsit,baik oleh air tanah maupun oleh intrusi air laut.Dari $31 \%$ air tanah yang mengalami evolusi tersebut, 3 sampel atau sekitar $6 \%$ memiliki tipe air $\mathrm{NaCl}$ yang mengindikasikan bahwa air tanah dangkal di tiga lokasi tersebut telah terkontaminasi air laut sebagai akibat intrusi air laut. Ketiga lokasi tersebut meliputi: Puri Anjosmoro, Tanah Mas dan Terboyo yang berada di dekat garis pantai Semarang. Di ketiga lokasi tersebut, faktor dilusi atau pengenceran oleh air hujan tidak mempengaruhi tipikal air tanah dengan tetap bertipe $\mathrm{NaCl}$. Berdasarkan Gambar 6 tersebut terlihat pula bahwa terdapat 6 sampel atau sekitar 12 memiliki tipe $\mathrm{NaCaHCO}_{3} \mathrm{Cl}$ yang merupakan tipe campuran antara air tanah tawar dengan air laut. Sebanyak 6 sampel air tanah lainnya atau sekitar $12 \%$ memiliki tipe $\mathrm{NaCaHCO}_{3}$.

\section{Peta lokasi sampel dan kontur ion klorida}

Gambar 7 memperlihatkan peta lokasi pengambilan sampel air tanag dangkal di beberapa lokasi di wilayah Kota Semarang. Berdasarkan peta tersebut terlihat bahwa sebagian besar sampel diambil di dataran aluvium Semarang dan sebagian lagi berasal dari daerah perbukitan yang terletak di selatan Kota Semarang. Sedangkan dari peta kontur ion klorida seperti terlihat pada Gambar 8, terlihat bahwa sebaran ion klorida dominan berada di area perkotaan khususnya di daerah Terboyo, Tanah Mas dan Sawah Besar. Sebaran lainnya mengarah ke daerah Puri Anjosmoro yang berada di sebelah baratnya. Fenomen ini sesuai dengan dugaan yang telah diperoleh berdasarkan analisis isotop stabil ${ }^{18} \mathrm{O}$ dan ${ }^{2} \mathrm{H}$ sebagaimana dibahas di atas.

\section{Parameter: Molar rasio Chloride Bicarbonate}

Berdasarkan data parameter molar rasio Chloride Bicarbonate yang ditunjukkan melalui grafik $\mathrm{Cl} /\left(\mathrm{CO}_{3}{ }^{2-}+\mathrm{HCO}_{3}{ }^{-}\right)$vs $\mathrm{Cl}^{-}$pada Gambar 9, terlihat bahwa terdapat dua

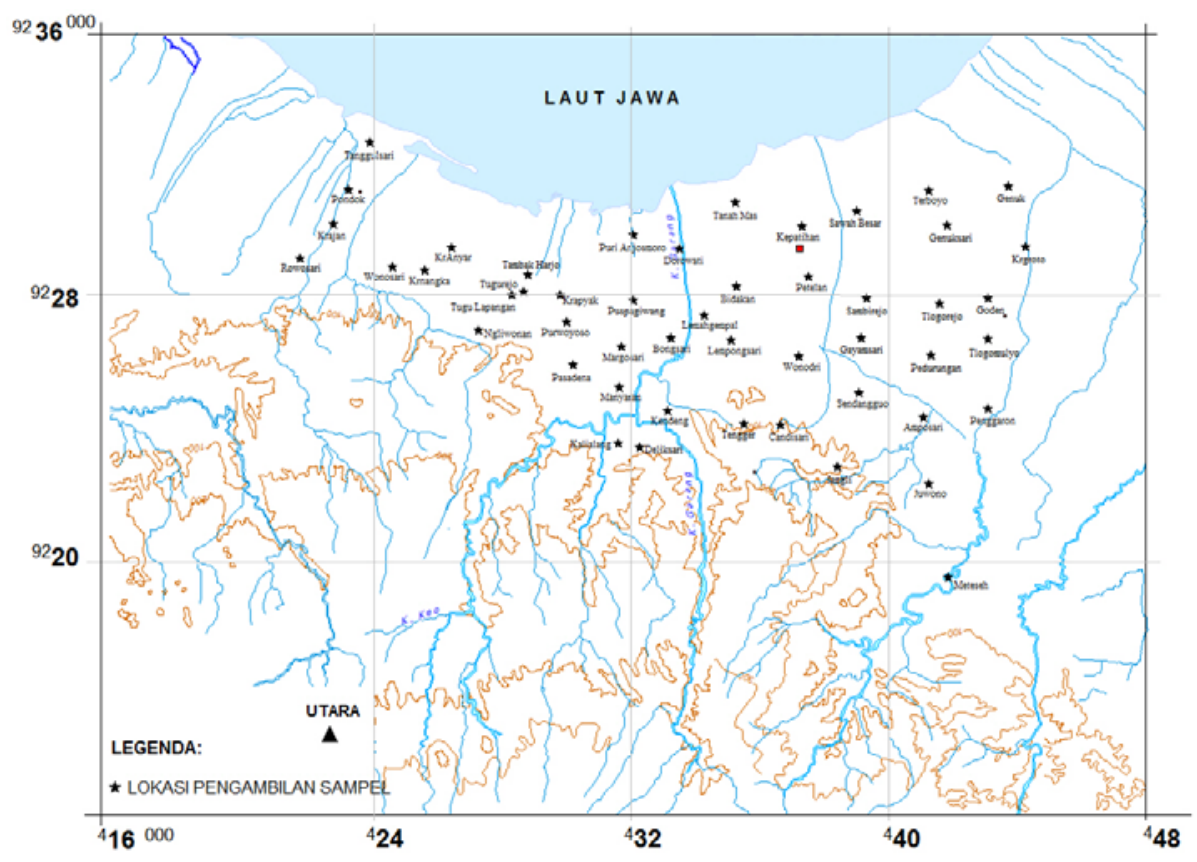

Gambar 7. Peta lokasi pengambilan sampel air tanah dangkal wilayah Kota Semarang 


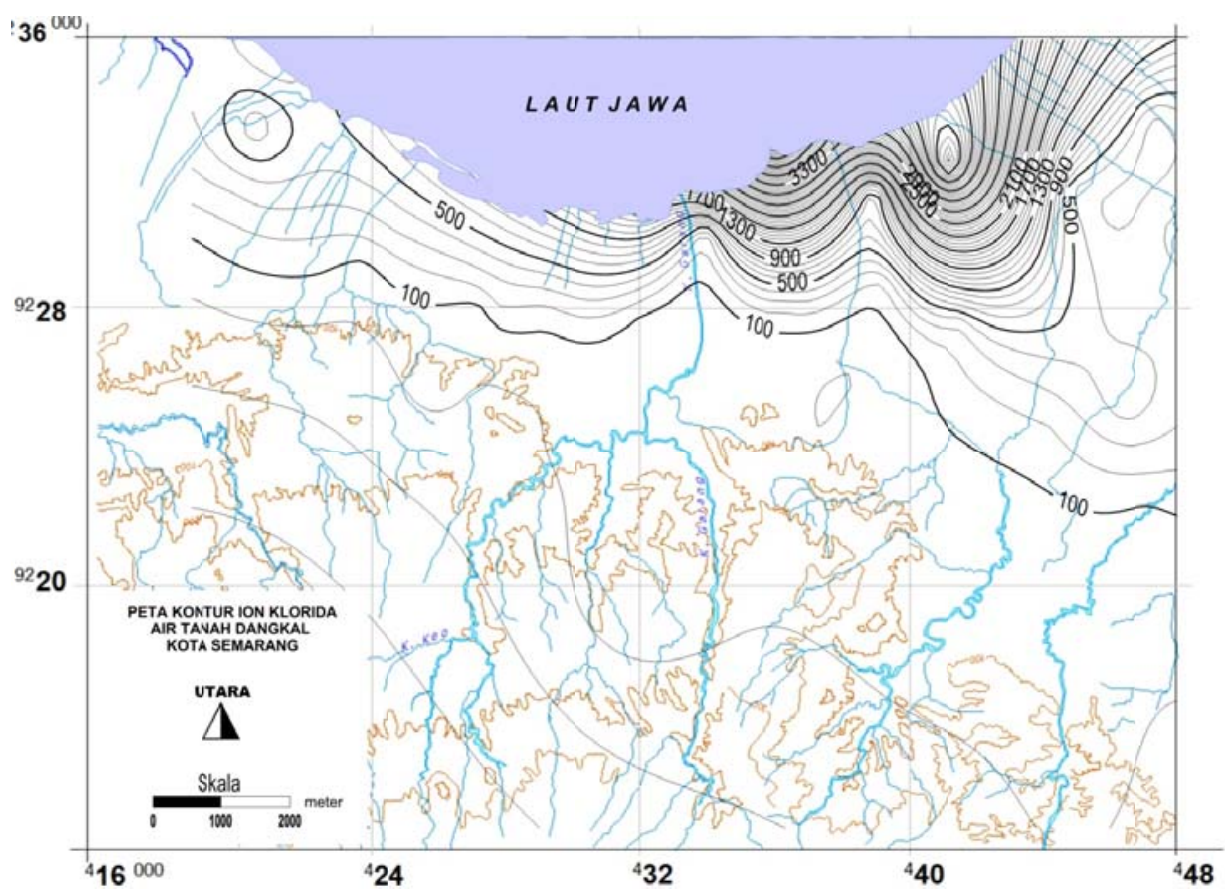

Gambar 8. Peta kontur ion klorida air tanah dangkal wilayah Kota Semarang

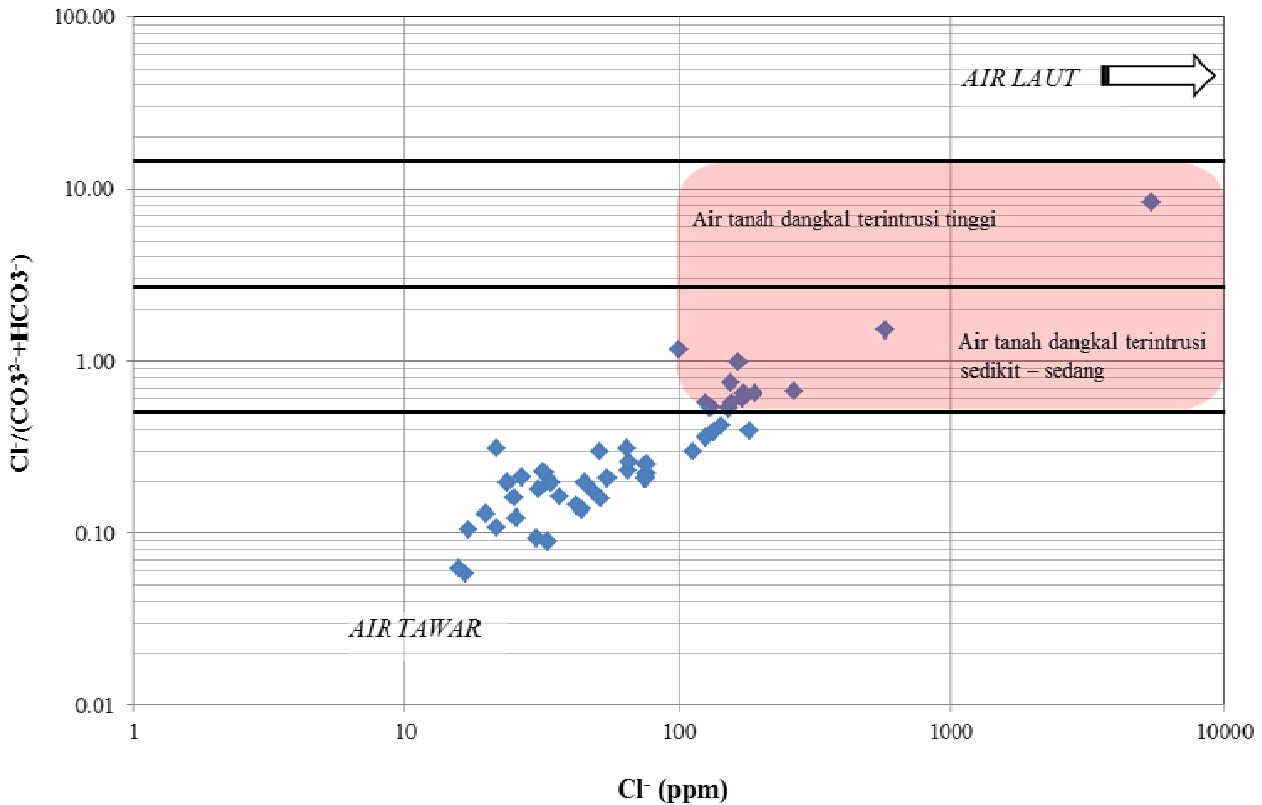

Gambar 9. Grafik hubungan rasio $\mathrm{Cl}^{-} /\left(\mathrm{CO}_{3}{ }^{2-}+\mathrm{HCO}_{3}{ }^{-}\right)$terhadap ion $\mathrm{Cl}^{-}$air tanah dangkal wilayah Kota Semarang pada musim penghujan

kelompok air tanah, yaitu kelompok air tanah tak intrusi dan intrusi. Kelompok air tanahdangkal tak terintrusi meliputi sebagian besar atau sekitar $78 \quad \%$ dari keseluruhan sampel dengan sebarannya secara umum dijumpaidi daerah kaki bukit hingga perbukitan di selatan Kota Semarang, yaitu di Semarang Barat dengan elevasi 
antara $13 \mathrm{~m}$ hingga $82 \mathrm{~m}$ dplSemarang Timur dengan elevasi antara $9 \mathrm{~m}$ hingga 142 m dpl. Sedangkan kelompok air tanah terintrusi meliputi sebagian kecil atau sekitar $22 \quad \%$ dari keseluruhan sampel. Sebarannya secara umum berada di dekat pantai dengan elevasi dengan elevasi antara $1 \mathrm{~m}$ hingga $13 \mathrm{~m}$ dpl. Daerah di Semarang Barat yang diduga terindikasi mengalami intrusi air meliputi: Tanggulsari, Pondok dan Tambak Harjo. Untuk Semarang Timur air tanah dangkalnya yang diduga terindikasi mengalami intrusi air laut meliputi: Puri Anjosmoro, Kepatihan, Tanah Mas, Terboyo, Sawah Besar dan Genuksari.

\section{KESIMPULAN}

Berdasarkan hasil analisis isotop stabil ${ }^{18} \mathrm{O}$ dan ${ }^{2} \mathrm{H}$ menunjukkan bahwa karakteristik air tanah dangkal pada saat musim penghujan sebagian besar cenderung berada di dekat garis meteorik Semarang. Dari keseluruhan sampel, 38 sampel atau sekitar 78 \%masih menunjukkan komposisi isotop stabil ${ }^{18} \mathrm{O}$ dan ${ }^{2} \mathrm{H}$ air meteorik dan 11 sampel atau sekitar $22 \%$ air tanah pada kelompok ini memiliki kandungan isotop ${ }^{18} \mathrm{O}$ dan ${ }^{2} \mathrm{H}$ yang relatif kaya (enrich) jika dibandingkan dengan air tanah lainnya. Dari 11 sampel atau sekitar $22 \%$ tersebut, 9 sampel atau sekitar $18 \%$ diantaranya berada di garis percampuran atau di garis mixing antara air tanah dangkal dengan air laut Semarang. Indikasi ini menguatkan dugaan bahwa pada 9 lokasi tersebut air tanahnya sudah terkontaminasi air laut. Ke sembilan lokasi tersebut terdiri atas Semarang Barat meliputi: Tanggulsari, Pondok dan Tambak Harjo serta Semarang Timur meliputi: Puri Anjosmoro, Tanah Mas, Kepatihan, Terboyo, Sawah Besar dan Genuksari.

Sementara itu, hasil yang ditunjukkan dari analisis kimia air menunjukkan karakteristik yang relatif sama sebagaimana telah diperlihatkan hasil analisis isotop stabil ${ }^{18} \mathrm{O}$ dan ${ }^{2} \mathrm{H}$. Data analisis kimia air (anionkation) dengan ionic balancesekitar $2,7 \quad \%$ menunjukkan bahwa pada saat musim penghujan, akuifer air tanah dangkal di wilayah Kota Semarang memilik tipe air dari $\mathrm{CaHCO}_{3}, \quad \mathrm{CaNaHCO}_{3}$ hingga $\mathrm{NaCaHCO}_{3}$ yang merupakan tipikal air tanah tawar dan sebagian lainnya bertipe $\mathrm{NaCl}$ yang merupakan tipikal air asin atau air laut. Demikian pula halnya data parameter Chloride Bicarbonate Ratio Ratio maupun kontur ion klorida menunjukkan bahwa sebagian besar air tanah di wilayah Kota Semarang pada saat musim penghujan masih berstatus air tanah tawar dan sebagian lainnya terkontaminasi air asin atau air laut. Lokasi-lokasi yang terkontaminasi air asin atau air laut tersebut relatif sama dengan yang telah diindikasikan sebelumnya melalui data isotop stabil ${ }^{18} \mathrm{O}$ dan ${ }^{2} \mathrm{H}$ di atas.

\section{UCAPAN TERIMA KASIH}

Terima kasih saya ucapkan kepada sdr. Setyo Budi dari Teknik Geologi Universitas Diponegoro Semarang yang telah membantu selama penelitian air tanah di Kota Semarang khususnya dalam pengambilan sampel air tanah dangkal dan air laut di beberapa lokasi.

\section{DAFTAR PUSTAKA}

1. SYAFALNI, Teknik Hidroisotop Untuk Analisis Keselamatan Lingkungan Tempat Pembuangan Akhir (TPA), Laporan Akhir Riset Unggulan Terpadu (RUT) (2002).

2. THOMAS, Permasalahan Air Tanah Pada Daerah Urban, TEKNIK, 30 (1), (2009).

3. http://www.Sinar harapan.co.id/index .html, Intrusi air laut (2007).

4. RAHMAWATI, N., \& MARFAI, M.A., Salinity Pattern in Semarang Coastal City, Indonesia Journal of Geology, 8 (2), June 2013, 111-120 (2013). 
5. WEST, A.G., FEBRUARY, E.C. and BOWEN, G.J., Spatial analysis of hydrogen and oxygen stable isotopes ("isoscapes") in ground water and tap water across South Africa, Journal of Geochemical Exploration, 145, 213-222 (2014).

6. HENDRAYANA, H., Intrusi air asin ke dalam akuifer di daratan, Universitas Gajah Mada, Yogyakarta (2002).

7. MTONI, Y., et.all., Saltwater intrusion and nitrate pollution in the coastal aquifer of Dar es Salaam, Tanzania, Environ Earth Sei, DOI 10.1007/s12665-012-2197-7., Springer-Verlag Berlin Heidelberg (2013).

8. MARSUDI, Prediksi Laju Amblesan Tanah di Dataran Alluvial Semarang-Jawa Tengah, Disertasi Program Doktor, Bandung, Institut Teknologi Bandung (2001).

9. SAID \& SUKRISNO, Peta Hidrogeologi Semarang, Badan Geologi (1988).

10. SWARZENSKI, P.W., et.all., A Combined Radio and Stable Isotopic Study of a California Coastal Aquifer System, Water 2013, 5, 480-504; doi: 10.3390/w5020480 (2013).

11. MONGELLI, G., et.al., Tracing Groundwater Salinization Processes in Coastal Aquifers: A Hydrogeochemical and Isotopic Approach in the $\mathrm{Na}-\mathrm{Cl}$ Brackish Waters of Northwestern Sardinia,
Italy, Hydrology and Earth Science, 17, 2917-2928 (2013).

12. YURTSEVER, Y., Role of Environmental Isotopes in Studies Related to Salinization Process and Salt Water Intrusion Dinamics, IAEA, Vienna, Austria (1993).

13. SOUNDARYA, A. AND PRAKASH, M., Assesment of Seawater Intrussion Into The Coastal Aquifers In Nellore District, Sri Venkateswara College of Engineering and Technology, Chittoor 517127, Andhra Pradesh, India (2014).

14. KLASSEN, J., ALEEN, D.M., and KIRSTE, D., Chemical Indicators of Saltwater Intrusion for the Gulf Islands, British Columbia. Final Report, Department of Earth Sciences, Simon Fraser University (2014).

15. TODD, D. K., Groundwater Hydrology, 2nd edition, john Willey \& Sons Inc., New York (1980).

16. ANDERS, R., et.all., Geochemical approach to determine sources and movement of saline groundwater in a coastal aquifer, Journal of National Ground Water Association, doi: 10.11111/gwat. 12108, USA (2013).

17. AL-KHATIB, M., Hydro-Geochemical characteristics of groundwater beneath the Gaza Strip, Journal of Water Resource and Protection, 3 (5), (2011). 